\title{
Recent Chinese Malaysians' Political Decision: A Matter of Rational Choice
}

\author{
Chin Yee Mun, Chang Yun Fah, and Wu Ming Chu
}

\begin{abstract}
In many multi-ethnic societies, ethnic politics plays an influential role in determining the outcome of elections. However, in these societies, voting decisions may also be influenced by their members' civic consciousness. This paper aims to explore the possibility that in a multi-ethnic society, voting decisions are made based on both ethnic and civic consciousness considerations. A study on Chinese Malaysians' voting decisions was conducted to investigate this phenomenon. Findings from this study show both factors play vital role in shaping Chinese Malaysians voting decision. This reflects the fact that a voter is rational and when he votes he will support any political party that is able to protect his interest be it in the form of ethnic rights or civic rights.
\end{abstract}

Index Terms - Ethnic, ethnic identity, ethnic socialization.

\section{INTRODUCTION}

Ethnicity has long been observed as one of the influential factors that determine the outcome of an election. Such observation has been made by scholars such as $\mathrm{M}$. Weber [1], C. Geertz [2] and M. Banton [3]. Weber opined that ethnic groupings are constructed by their members through a shared belief that they are somehow related. The shared belief unites the members and allows the ethnic groupings to act as collective political units. Geertz made a more or less similar conclusion when observing South-East Asians responses to political changes that affect them in the midtwentieth century. It was within this particular period of time, countries such as Indonesia and Malaya (which became part of Malaysia in 1963) obtained their independence and formed. As they were preparing for the formation of their countries, ethnic served as a unifying factor that gathered people who assumed they had 'blood ties'. The assumption was mobilized by them to form collective political action groups.

There were strong collective ethnic movements and each movement strived to champion the rights and benefits of their ethnic group. Hence, as suggested by Banton, ethnic groupings were formed out of necessity. He described the belief that one belongs to an ethnic group as a form of consciousness that is driven by rational choice. Consequently, the consciousness plays an important role in determining his or her political decision.

In the context of Malaysia, scholars such as R. K. Vasil [4], K.L. Ho [4] and F. Holst [5] viewed ethnic as one of the

Manuscript received January 20, 2014; revised March 31, 2014.

Chin Yee Mun and Wu Ming Chu are with the Faculty of Creative Industries, UTAR, Selangor, Malaysia (e-mail: chinym@utar.edu.my, wumc@utar.edu.my).

Chang Yun Fah is with the Faculty of Engineering and Science, UTAR, Selangor, Malaysia (e-mail: changyf@utar.edu.my). most important factors that determine Malaysians' political decision. Although these scholars applied different analytical tools when analyzing Malaysia's political climate, their views pointed out that Malaysia's political atmosphere is highly ethnicized at both the structural and also the individual levels. Malaysians utilized their ethnic groups as a form of tool to fulfill their collective political needs.

Nevertheless, recent political trends in Malaysia have been said to indicate otherwise. The results of the Malaysia's $13^{\text {th }}$ General Election (GE), for instance were interpreted from contradicting perspectives. Certain quarters interpreted the results as an outcome of ethnic politics while some interpreted it as an outcome of increasing civic consciousness.

Such interesting arguments arose after claims that Chinese Malaysians had voted collectively against Barisan Nasional (BN), the ruling coalition. The perceived Chinese Malaysians' collective action was then referred to as Chinese tsunami. Many BN leaders including the chairman of BN, Najib Tun Razak had this perception. They justified their claim by referring it to the huge losses of Chinese based political parties within BN such as Malaysian Chinese Association (MCA), Gerakan and Sarawak United People's Party (SUPP). BN was only able to win four out of the forty six parliamentary seats where Chinese Malaysian formed the biggest group of voters. The rest of the seats were won by Democratic Action party (DAP) and Parti Keadilan (PKR). DAP and PKR are component parties of Pakatan Rakyat (the opposition coalition).

In reacting to such claim, certain parties which include leaders of Malaysia's opposition parties such as Lim Kit Siang claimed that the GE13 results had nothing to do with ethnic politics. They described the results as outcomes of BN inability to curtail problems that were caused by BN's poor governance. They claimed that $\mathrm{BN}$ was unable to resolve problems faced by Malaysians such as inflation, rising crime rates, corruption, environmental issues and etcetera. This had caused the support for BN to dwindle in GE13. Further analysis from this perspective highlighted that $\mathrm{BN}$ losses were mainly in urban areas where the middle-class Malaysians formed a large proportion. Their socio-economic position allowed them to be more vocal. At the same time access to internet provided them alternative information that was different from the information provided by mainstream media, which were perceived as controlled by the ruling coalition. Consequently, proponents of this perspective relate $\mathrm{BN}$ losses to urban tsunami. Henceforth, proponents of the urban tsunami perspective reinvigorated that the results of Malaysia's $13^{\text {th }}$ GE should not be read as the result of Chinese Malaysians' collective political action. For these proponents, BN' losses in this election was caused by the higher civic awareness among 
Malaysians.

Based on such background, this paper would like to explore the possibility that both factors; ethnic and civic consciousness play an important role in shaping the Chinese Malaysians' political decisions. A study into this matter is important as it provides an avenue for an in-depth discussion on the nature of their political decisions. As presented earlier, ethnic can be used as a factor to generate collective political action. Will civic consciousness be able to generate such effect too? Could the Chinese Malaysians strong opposition towards $\mathrm{BN}$ in the $13^{\text {th }} \mathrm{GE}$ reflect that both factors can reinforce each other? In order answer these questions; this paper will be discussing whether Chinese Malaysians are still voting collectively as an ethnic group to champion their ethnic group rights. This paper will also explore Chinese Malaysians' civic consciousness and explain the effect of such consciousness on their political decisions. Lastly, this paper will examine the fluidity of Chinese Malaysians' collective political action. If indeed the collectiveness is fluid i.e. not fixed and may change according to circumstance, it will portray them as a group of rational voters who may make their political decision based on ethnic factors, civic factors or a combination of both factors. In other words, this paper is suggesting that their political decisions are dynamic and will be affected by what they think will be best for them.

\section{Past Chinese Malaysians' Political Decisions}

Being a community that was and still referred to as the 'migrant community', Chinese Malaysians took part in the making of a nation that was highly communal. This observation was made by K.J. Ratnam [7]. As Malaya was about to achieve its independence in 1957, Malayans were deeply engrossed in the contestation of rights between Malays and non-Malays. The Malays would like to retain their status as the rightful owner of Malaya while the nonMalays which consisted of Chinese and Indians would like Malaya to be a nation that recognized them as equal citizens. The contestation was later discussed by A.B. Shamsul [8] as the contestation of 'nation of-intent'. For Chinese, Malaya should be a multi-ethnic nation that accept and treat all Malayans as equals. On the contrary, Malays assumed Malaya as their nation and other communities should respect and accept their position. According to J. Chin [9], the contestation continued after Malaya achieved its independence and went on even after Malaya became part of Malaysia in 1963.

However, what was the underlying factor that drove Malays and Chinese to have contesting nation of-intent? C. Hirschman [10] linked the contestation between the two communities to British 'divide and rule' policy. According to Hirschman, British segregated the communities to facilitate their rule. Consequently, the segregation caused the contestation to emerge. Hirschman's proposal carries some sense if one considers ethnic consciousness is constructed through the top-down perspective. Nonetheless, if one analyzes its formation from the bottom-up perspective, one will see that ethnic consciousness is constructed by individuals, often for reasons associated to their politicoeconomic needs.
J. Nagata [11] highlighted that such phenomenon occurred in Malaysia. According to her, some Malaysians would identify themselves as members of different ethnic group in different situations. They would claim that they were members of a particular ethnic group if they saw the need to do so. Therefore, ethnic consciousness can be socially constructed. In the context of Chinese Malaysians, it has been observed that their consciousness would be strong when they felt that their politico-economics rights were threatened. P.K. Heng [12] and K.P. Thock [13] made this observation when analyzing Chinese Malaysians responses to Malay hegemony. Often, when they felt their rights were threatened, they would support the opposition political parties to keep BN and its component parties' incheck. This will prove the fact that ethnic consciousness can be turned into an important factor that influences their political decisions. It also proves that the nation of-intent contestation between the Malays and the Chinese Malaysians are by and large caused by the contestation of politico-economic needs at the individual level.

Past Chinese Malaysians political decisions have shown that they had been voting in accordance to what they think as best for their community. In his paper, C. H Wong [14] commented that Chinese Malaysians had split their votes to support both the opposition parties; mainly DAP and BN. In some GE, they would give more votes to $\mathrm{BN}$ but in some other GEs; they gave their votes to the opposition. Although, the split voting trend would create the presumption that the Chinese Malaysians votes were fragmented, a more concise analysis would show that split voting was merely their strategy to keep the ruling and opposition parties in-check. By giving more support to either one side, political parties from both sides of divide have to pay more attention to their needs.

The discussions above deliver the point that Chinese Malaysians are primarily concern about the well-being of their ethnic group. If this true, it will mean that they will not consider other factors such as the well-being of their nation. This paper would like to argue that they do take into consideration other factors. Being the second largest ethnic group in Malaysia, they will be strongly affected if the country is not well administered. Therefore, civic consciousness; a sense of responsibility, commitment and belonging to a nation, will play an important role in shaping Chinese Malaysians' political decisions. This is reflected in an analysis conducted by Maznah Mohammad [15]. According to her, concerns over the incapability of $\mathrm{BN}$ to contain corruption, increasing cost of leaving as issues related to human rights had caused the support for the coalition to deteriorate in the $12^{\text {th }} \mathrm{GE}$. BN's Chinese based component parties suffered huge losses in this election.

\section{RESEARCH Methodology}

A survey was conducted through Universiti Tunku Abdul Rahman's (UTAR) opinion poll portal - MyPoll. MyPoll has more than 12000 registered poll's participants. More than 90 per cent of them are Chinese. The survey questions were uploaded into the portal in two stages. For each stage, the questions were posted for two weeks. During the first stage, questions posted into the portal were designed to test 
respondent's ethnic consciousness. At the second stage, the questions focused on civic consciousness. Due to the multiethnic nature of the MyPoll's database, the survey questions were designed to capture opinions from respondents who might originate from different ethnic background. However, at the analysis stage, only data contributed by the Chinese respondents were analyzed. Following are the details of the Chinese respondents' who had participated in the survey:

- Total valid Chinese respondents (respondents who answered both sets of questions): 820 respondents.

- Sex: $50.1 \%$ female and $49.9 \%$ male.

- Age group: $28.4 \%$ of respondents were below 21 yearold and not eligible to register as voter. For those who were eligible to register as voter, $59.4 \%$ were within 21 to 25 year-old, $6.3 \%$ were from 26 to 30 year-old, $3.2 \%$ were from 31 to 35 year-old and $2.7 \%$ were above 35 year-old.

- State of origin: the largest groups of respondents originated from Selangor $(28.2 \%)$, Perak $(22.1 \%)$ and Kuala Lumpur (18.7\%). 8.8\% and $7.0 \%$ of respondents were from Johor and Penang, respectively. Respondents from other states were less than or equal to $5 \%$.

Further study was done through qualitative method to get qualitative data to generate more details on the effect of ethnic and civic consciousness on Chinese Malaysians' political decisions. Five focus groups discussion (FGD) were held. There were six to eight members in each FGD. Time spent for each FGD was approximately one and a half hour. The following table (Table I) describes the FGD participants' profile.

TABLE I: FGD PARTICIPANTS SELECTION PROFILE

\begin{tabular}{|c|c|c|}
\hline Groups & Quantity & Profiles \\
\hline Youth & Two & $\begin{array}{l}\text { Age: } 18-25 \\
\text { Gender: Male and Female } \\
\text { Occupation: Students and young } \\
\text { working adults }\end{array}$ \\
\hline $\begin{array}{l}\text { Lower } \\
\text { income }\end{array}$ & One & $\begin{array}{l}\text { Age: Mix } \\
\text { Gender: Male and Female } \\
\text { Occupation: Income below } \\
\text { RM3000 }\end{array}$ \\
\hline $\begin{array}{l}\text { Middle } \\
\text { income }\end{array}$ & One & $\begin{array}{l}\text { Age: Mix } \\
\text { Gender: Male and female } \\
\text { Occupation: Income within } \\
\text { RM3000 and RM10000 }\end{array}$ \\
\hline $\begin{array}{l}\text { High } \\
\text { income }\end{array}$ & One & $\begin{array}{l}\text { Age: Mix } \\
\text { Gender: Male and Female } \\
\text { Occupation: Income above } \\
\text { RM10000 }\end{array}$ \\
\hline
\end{tabular}

\section{FINDINGS AND DISCUSSION}

Results obtained from the survey and FGD show both forms of consciousness affect the respondents' political decisions. Hence, the respondents were ethnically conscious and such consciousness affects their political decision. Most of them identified themselves as Chinese and they believed Chinese rights in Malaysia had been compromised. In term of national identity, they identified themselves as Malaysian and just like their ethnic rights; they felt there were certain civic issues affecting this country. Although, both form of consciousness were more or less equally high, their choice of political parties showed otherwise. Most of them preferred non-ethnic based parties. Thus, such preference requires explanation. Why would they prefer to support non-ethnic based parties when there were indications to prove that they were concerned about Chinese position in Malaysia? In order to provide an answer for this question, the following sections in this paper will attempt to describe the respondents and FGD participant views on this matter. The following sections also contain elaborations on the nature of the respondents' ethnic and civic consciousness' influence on their political decisions.

\section{A. Ethnic Consciousness still Plays an Important Role in Shaping Chinese's Voting Decision.}

In order to answer the first research questions, the survey questions tested the respondents' ethnic consciousness on their political decisions. Respondents were asked to state the level of their agreement on statements that were related to a person's ethnic identification, ethnic boundary, basis to form ethnic collective action and their tendency to use their ethnic group to form collective political action. The level of agreement (strongly disagree to strongly agree) was measured by using a five point likert scale. Each of the statements carried a score of five, ranging from one (strongly disagree) to five strongly agree). Since there were five statements that tested each of the items mentioned above, the total score for each item was 25 . The respondents were also asked to state the nature of political party that they would support. There were given four options, namely ethnic based party, civic based party, ideology based party and religion based party. The last section of the survey questions required the respondents to state issues that would have affected their ethnic group. During FGD, participants were asked to explain further on matters that were related to the statements presented in the survey.

TABLE II: MEAN AND MEDIAN SCORE FOR ITEMS RELATED TO EFFECT OF RESPONDENTS' ETHNIC CONSCIOUSNESS ON THEIR POLITICAL

\begin{tabular}{llll}
\hline \hline & Mean & Median & $\begin{array}{l}\text { Standard } \\
\text { Deviation }\end{array}$ \\
\hline Ethnic Consciousness & 71.05 & 75 & 16.4 \\
Ethnic Boundary & 50.5 & 50 & 15.1 \\
$\begin{array}{l}\text { Basis for Ethnic Collective } \\
\text { Action }\end{array}$ & 71.5 & 70 & 14.6 \\
$\begin{array}{l}\text { Tendency to Form Ethnic } \\
\text { Political Action }\end{array}$ & 62.5 & 65 & 16.2 \\
\hline \hline
\end{tabular}

Based on the data obtained through the survey and FGD, there are evidences to show that ethnic consciousness still play an important role in shaping Chinese Malaysians' voting decision. Such conclusion is supported by the fact that most of the respondents are ethnically conscious. Many of them felt that Chinese in Malaysia had been mistreated and such perceptions had caused them to think that they needed to form collective political action. The result of the survey (refer to Table II) shows the median score for questions that tested the respondents ethnic consciousness is 75 while the mean score is 71.05 . This means most of the respondents identified themselves as Chinese and they related their Chineseness to their language, tradition, beliefs and other cultural elements. Data obtained from the FGD show similar indication. One of the FGD participants, $\mathrm{CH}$ said, "Because we're born Chinese, that's it. I don't see the 
reason for categorizing it... trying to make ourselves more Chinese or less Chinese? Chinese is Chinese. That's it." CH's statements indicate high ethnic consciousness. Another participant, WJ also identified himself as Chinese. He related his Chineseness to his name. According to him "... the name by itself will reflect that I am a Chinese. If my name has changed, then I am nothing."

The above explanations show most of the respondents identified themselves as Chinese. However, their ethnic consciousness did not cause them to develop strong ethnic boundary. The mean score for the statements related to ethnic boundary is 50.5, a moderate score. Even though their ethnic consciousness is high, it will not stop them from interacting with members of other ethnic groups. This could be due to fact that in a multi-ethnic country, it is impossible for the respondents to ignore members of other ethnic groups. As rational and pragmatic individuals the respondents will interact with members from other ethnic groups albeit with some concerns. Their concerns might have caused their ethnic boundary to be moderate, i.e. not low too. This conclusion is visible in WT assumption about his relations with members of other ethnic groups in Malaysia. He said, "Actually... when we are with others, we're very friendly to each other... but at the back there could be prejudices and stereotyping, the same goes for them..."

Although their ethnic boundary score is moderate, they did perceive Chinese position in Malaysia had been compromised and therefore they should unite to safeguard their position. The mean score for statements that touches on the Chinese basis to form collective action is 71.5, a high score after considering the fact that the total score is 100 . The median score for these statements are 70. Many of the FGD participants expressed such perception. According to KT "Chinese... cannot get fair treatment, there are still inequalities." These feelings caused many of the respondents to think that Chinese must unite politically. According to $\mathrm{KN}$, "Election is the opportunity for change. Through the change... we hope we will be treated fairly." In his views, Chinese Malaysians must make use of election to form a government that will be able to treat Chinese fairly. The survey results also shows that many respondents feel Chinese in Malaysia should form collective political action. The mean score for statements that touches on their tendency to mobilize collective political action is 62.5 with a median score of 65 , a moderately high score.

Interestingly, in spite of all the indications that indicated ethnic consciousness did affect the respondents' political decision, many of them preferred to support non-ethnic based parties. 92.9 percent of the respondents indicated that they preferred non-ethnic based parties. Only 7.1 respondents preferred ethnic based parties. What could have caused such preference? Answer for this question, can be found in some of the FGD. Many participants felt the current Chinese based parties within BN coalition were not able to represent the Chinese. One of the participants, GR said. "I cannot guarantees that DAP will fight for Chinese's right, but they are our best hope if compared to other Chinese based parties." GR's view was shared by WJ. In WJ's view, "I think majority Chinese will support Chinese based parties. But in certain occasion, if the parties are not able to solve Chinese's problem... after sometime... the Chinese will not support them anymore" WJ's view also indicates that Chinese Malaysians are pragmatic and rational. It shows Chinese Malaysians are willing to support any party that will bring benefit to them. In other words, this would mean that when they support a non-ethnic based party, it does not necessary mean that they had forgotten their collective needs. Furthermore, DAP has been perceived as a Chinese based parties too. Most of DAP members are Chinese. Its political objective is to maintain the multi-ethnic nature of this country. Most Chinese Malaysians, at present, have similar thoughts. Through the recognition that Malaysia is a multi-ethnic country, they hope a fairer that treats them as equal citizen can be formed. The common objective eventually attract Chinese Malaysians to support DAP.

\section{B. Chinese Malaysians' "Multi-Ethnic Civic Consciousness" Would Like to See Malaysia Progress and Its People to Enjoy Good Governance.}

The second set of survey questions was uploaded two weeks after the first set. The second set of survey questions required respondents to state their level of agreement to a series of statements related to their civic consciousness. Just like the first survey, the statements presented in the second survey were measured by using a five point likert scale. Each statement carries a maximum score of five. The statements tested respondents' level of agreement on four items. The items were civic identification, civic boundary, basis for civic collective action and their tendency to mobilize their civic consciousness to form collective political action. Each item was tested by five statements. Since each statement carried a score of five, the total score for each item was 25 . The overall total score for these items was 100. Respondents were also asked to choose their preferred type of political parties. The choices given to them were similar to the choices given in the first set of questions. The final section of the questionnaire required respondents to indicate issues that they would perceive as affecting the nation. During the FGD, participants were asked to elaborate on matters related to items mentioned above.

Most of the respondents of the second survey put their nation's priority as their priority. They also felt that they were responsible to contribute to the development of Malaysia. In other words, the respondents of the second survey (who had completed the first survey) civic consciousness was high. As shown in Table III, the mean score for statements related to the respondents' civic consciousness was 72.5. Their high civic consciousness was also exhibited when all the FGD respondents identified themselves as Malaysian. Such identification reflects that they accepted Malaysia as their nation. When asked to elaborate on the meaning of 'Malaysian', most of the respondents pointed out that it was about accepting the multi-ethnic nature of Malaysia. The acceptance was internalized through practicing and blending into Malaysia's diverse and multi-ethnic culture. This acceptance was reflected in some of the comments made by the FGD's participants about their Malaysian identity. According to KL, "We usually speak mixture of Chinese, Malay and English in a sentence." His statement clearly shows that he has 
accepted the diversity of languages used by Malaysians and he has blended the languages to what he assumed as the Malaysian language. Another participant PG, shared similar view and was proud of Malaysians capabilities to blend different languages into one sentence. She said, "Actually I have a Taiwanese friend. He admired the Malaysian Chinese a lot because we can speak Malay, Chinese, English and even some can speak in Tamil too." Besides language, some of the FGD's participants felt that being Malaysian would also mean being able to share common everyday life practices. One of such participant was $\mathrm{CH}$. He felt Malaysians shared many commonalities. He said, “... Every aspect, everything, education, the way we talk, what we like to eat, what we like to watch on television, even the football, and recently thanks to election, the topic in mamak store..."

TABLE III: MEAN AND MEDIAN SCORE FOR ITEMS RELATED TO EFFECT OF RESPONDENTS' CIVIC CONSCIOUSNESS ON THEIR POLITICAL

\begin{tabular}{llll}
\hline \hline & Mean & Median & $\begin{array}{l}\text { Standard } \\
\text { Deviation }\end{array}$ \\
\hline Civic Consciousness & 72.5 & 75 & 14 \\
Civic Boundary & 63 & 65 & 15.7 \\
Basis to Form Civic Collective & 78 & 75 & 13.7 \\
$\begin{array}{l}\text { Action } \\
\text { Tendency to Form Civic Political }\end{array}$ & 78 & 75 & 13.7 \\
Decision & & & \\
\hline \hline
\end{tabular}

Based on the above elaborations, it is obvious that the respondents and FGD's participants are conscious of their Malaysian identity and also feel obliged to commit themselves to safeguard the interest of this country. The obligation caused many of them to develop moderate civic boundary. The mean score for civic boundary is 63 . The score indicates that their civic consciousness may influence their interactions with other Malaysians to some extent. They may not accept other Malaysians who do not share their feelings about Malaysia.

The second survey results reflect that the respondents were highly concerned about the Malaysia's well-being. The mean score for the basis to form civic collective action is 78 with a median score of 75 . The high mean score indicated that the respondents were worried about their country's future and would not hesitate to work collectively with other Malaysians to preserve the well-being of their country. Remarks made the FGD's participants describe such worries. Many of the remarks were about BN's poor governance. One of such remarks was made by CG. According to her, "They (the government officials) are more concern about fancy stuff. We suspect behind the scene... corruptions. The projects initiated by them never have good result... Delay after delay and they never explain why. They just do what they want but not what we need." CG's remark revealed her frustration and concern about the state of BN governance.

These feelings may cause the respondents to act collectively through political channels. Such tendency was shown when most the respondents agreed that they would stand up to preserve Malaysia's well-being. They felt civic based political parties were relevant; an indication that they would use civic based parties to protect Malaysia's wellbeing. Such decision was shown when more than 70.2 per cent (refer to Table IV) of the respondents chose civic based parties as their choice.

TABLE IV: RESPONDENTS' SUPPORT FOR VARIOUS CATEGORIES OF POLITICAL PARTIES

\begin{tabular}{ll}
\hline \hline Categories of Political Parties & Percentage of Support \\
\hline Civic Based & 70.2 \\
Ideology Based & 22 \\
Ethnic Based & 7.1 \\
Religion Based & 0.7 \\
\hline \hline
\end{tabular}

Judging from the above discussions, it can be concluded that Chinese Malaysians have high civic consciousness. Their high civic consciousness is understandable since they have accepted the fact that they are Malaysian. As Malaysian, it will only be rational if they participate in the political processes that will create a better Malaysia. At the time this study was conducted many Chinese Malaysians felt that the BN government had failed to govern this nation well. The pragmatic measure used by them was to reject BN and to do that they would ensure all $\mathrm{BN}$ component parties were rejected too. This measure was employed by the Chinese in the $13^{\text {th }}$ General Election. As a result, all Chinese based parties in BN were not able to garner support from the Chinese community.

\section{Chinese Prefer a Multi-Ethnic Civic Based Party to Represent Them.}

The discussion above highlighted the importance of civic consciousness in determining Chinese Malaysians' political decision. Figure 1 compares the total civic consciousness score and the total ethnic consciousness score for respondents who indicated they would support ethnic based parties and those who would support non-ethnic based parties. For those who indicated that they would support non-ethnic-based party, their overall civic consciousness score (median score is 72.5, average score is 73.3) was significantly higher than their overall ethnic consciousness score (median score and average score are 63.8) at 0.05 level of significance. However such was not the case for respondents who chose to support ethnic based parties. Their overall civic consciousness score (median score is 70 and average score is 68) was merely slightly higher than the overall ethnic consciousness score (median and average scores are 66.3).

The above analysis indicated that the respondents who chose non-ethnic based parties' civic consciousness might have played more roles in shaping their political decision. For respondents who chose to support ethnic based political parties, the difference between ethnic and civic consciousness was unclear. Since most of the respondents (92.2 per cent) who participated in this research chose nonethnic based parties, this research proposed that civic consciousness played a more determining role in shaping Chinese Malaysians' political decision.

These findings support the fact that Chinese Malaysians are rational and pragmatic in their political decisions. Even though their ethnic and civic consciousness was strong, this consciousness did not cause them to treat others differently. Discussion in the earlier sections shows that the respondent's ethnic and civic boundaries are moderate. In other words, they could be individuals who would make 
decision based on circumstance. Since the civic issues raised by them (as shown in Table $\mathrm{V}$ ) are issues that will affect their everyday life; these issues would certainly affect their political decision. Such pragmatism was clearly highlighted by one the FGD's participants. According to SF, "Err... I think we will support a party that really takes care of us and not necessary based on ethnic. Like what PG had said, supporting multiracial.... right? If a multiracial party takes care of each of us, I'll support. No matter the party is Chinese, Indian or Malay. As long as we feel like we're being taken care of." However, at present, BN's Chinese based parties were perceived as incapable of solving these issues. Hence, many of them decided to support civic based parties. As indicated in the last election, Chinese Malaysians assumed DAP could solve these issues effectively if the party became the governing party.

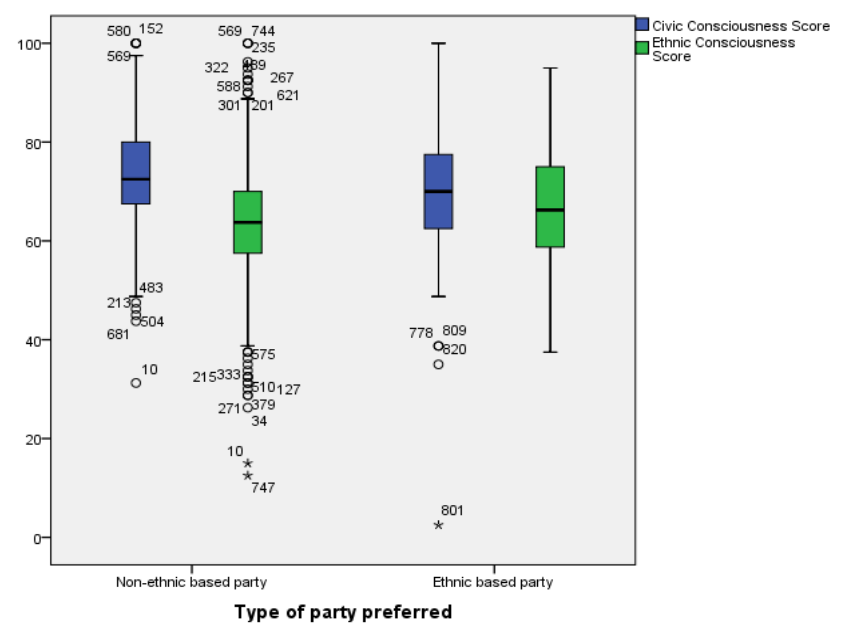

Fig. 1. Effect of ethnic and civic consciousness on respondents' choice of political party.

TABLE V: IsSUES AND PERCENTAGE OF RESPONDENTS (CHOSE NON ETHNIC BASED PARTIES) WHO FELT THESE ISSUES AFFECTED MALAYSIA'S WELL BEING

\begin{tabular}{lll}
\hline \multicolumn{1}{c}{ Issues } & Percentage & Rank \\
& & \\
\hline Security & $70.7 \%$ & 1 \\
Integrity & $63.8 \%$ & 3 \\
Education & $70.7 \%$ & 1 \\
Economy & $70.7 \%$ & 1 \\
Human Rights & $67.2 \%$ & 2 \\
Costs of Living & $63.8 \%$ & 3 \\
Environment & $53.5 \%$ & 4 \\
\hline \hline
\end{tabular}

Even so, it should be noted that the respondents' ethnic consciousness was not low either. Judging from their total ethnic consciousness score, ethnic factor do play some roles in shaping Chinese Malaysians' political decision. As discussed earlier, some of the FGD's participants defined Malaysian as someone who accepts the multi-ethnic nature of the Malaysian society. Within such identity, they hoped all Malaysians would accept and treat each other equally and fairly. They expect other Malaysians to accept similar definition. Thus, when they perceived certain social arrangements in Malaysia were not according to what they were expecting, they felt Chinese in Malaysia had been oppressed. They were looking for a political party that could protect them and voice their concerns effectively.

\section{CONCLUSION}

Summarily, Chinese Malaysians' political decision is shaped by their civic and ethnic consciousness. They are concerned about Malaysia's well-being and such concern will cause them to support any political parties that are able to govern Malaysia well. At the same time, they will support a party that can ensure all Malaysians are treated equally and fairly.

From the findings of this research; it is clear that in a multi-ethnic society, ethnic consciousness is not the only factor that influences the political atmosphere. Members of such society such as Chinese Malaysians do take into consideration the importance of their roles as a citizen of Malaysia. They realized the importance of enhancing the well-being of their country.

Therefore, political decisions in such society are dynamic. Members of a multi-ethnic society will take into consideration an array of factor before deciding. This signifies rationalization. Being voters, members of a multiethnic society will choose a party that can serve them best. Their interest could be in the form of ethnic rights. It could also be in the form of their hope that they will be able to leave in a society that is well-governed. There is also a possibility that they want both. Thus, it really depends on what an individual construct the meaning of what he needs. Therefore, this paper would like to propose that recent Chinese Malaysians political decisions are made based on what they think is the wisest choice.

As a result of such rationalization, their support for certain political party will change according to time. Although, at present, Chinese Malaysians may seem to have rejected $\mathrm{BN}$, such trend may change. Being rational individuals, their decisions are not static. They may support $\mathrm{BN}$ again if for example they find the party again has transformed and able to bring positive change to this country.

\section{REFERENCE}

[1] M. Weber, "What is ethnicity?" The Ethnicity: Nationalism, Multiculturalism and MIgration, by G. Rex and J. Montserrat, Cambridge, Polity, pp. 15-26, 1997.

[2] C. Geertz, The Interpretations of Culture, London, Hutchinson \& Co, 1973

[3] M. Banton, "A theory of social category," Sociology, vol. 45, pp. 187201, 2011

[4] R. K. Vasil, Ethnic Politics in Malaysia, New Delhi, Radiant Publishers, 1973.

[5] K. L. Ho, "Imagined comunion, irreconcilable differences? Perceptions and responses of the Malaysian Chinese towards Malay political hegemony," in Chinese Studies of the Malay World, by C. Ding and K. Ooi, Singapore, Eastern University Press, pp. 239-262, 2003.

[6] F. Holst, Ethnicization and Identity Consctruction in Malaysia, London, Routledge, 2012.

[7] K. J. Ratnam, Communalism and the Political Process in Malaya, Kuala Lumpur: University of Malaya Press, 1967.

[8] A. B. Shamsul, "Debating about identities in Malaysia: A discourse analysis," Southeast Asian Studies, vol. 34, no. 3, pp. 476-499, 1996.

[9] J. Chin, "Malaysian Chinese politics in the 21st century: fear, service and marginalization," Asian Journal of Political Science, vol. 9, no. 2, pp. 78-94, 2001. 
[10] C. Hirschman, "The making of race in colonial Malaya: political economy and racial ideology," Sociological Forum, vol. 2, pp. 330$361,1986$.

[11] J. Nagata, Malaysian Mosaic: Perspectives from a Poly-Ethnic Society, Vancouver: University of British Columbia Press, 1979.

[12] P. K. Heng "Chinese responses to Malay Hegemony in Peninsular Malaysia 1957-96," Southeast Asian Studies, vol. 34, no. 3, pp. 500$523,1996$.

[13] K. P. Thock, Ketuanan Politik Melayu: Pandangan Kaum Cina. Kuala Lumpur, UM Press, 2007.

[14] C. H. Wong, "The end of Chinese Malaysians' political division? The March 8 Political Tsunami and Chinese Politics in Penang, Selangor and Perak," in Malaysian Chinese: Recent Developments and Prospects, by H. G. Lee and S. Leo, Singapore, ISEAS, pp. 86-108, 2012.

[15] M. Mohammad, "Malaysia-democracy and the end of ethnic politics?" Australian Journal of International Affairs, vol. 62, no. 4, pp. 441459, 2008.

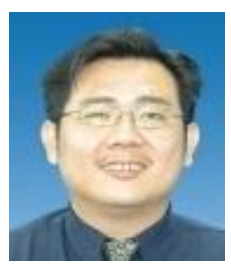

Chin Yee Mun obtained his Ph.D in the field of social psychology from Universiti Putra Malaysia. Currently, he is an assistant professor in Universiti Tunku Abdul Rahman (UTAR). His main research interest is in the area of ethnic relations, ethnic politics and cultural studies.

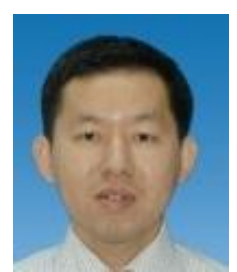

Chang Yun Fah is an assistant professor in Universiti Tunku Abdul Rahman, Malaysia. He received the B.A. degree in mathematics, M.Sc. degree and $\mathrm{Ph} . \mathrm{D}$. degree in applied statistical from University of Malaya, Malaysia. His research interest is in applied statistics, functional linear models, image and video analysis, and pattern recognition.

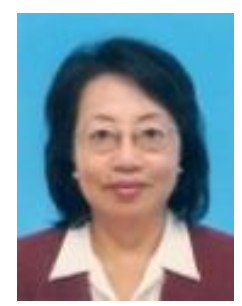

Wu Ming Chu obtained her Ph.D. in social sciences from Institute of Higher Leraning, Universit Malaya. Presently she is attached to Universiti Tunku Abdul Rahman. Her research interests are in overseas Chinese studies, gender, and social economics studies. 